\title{
IJCIT
}

(Indonesian Journal on Computer and Information Technology) Journal Homepage: http://ejournal.bsi.ac.id/ejurnal/index.php/ijcit

\section{Sistem Pendukung Keputusan Penerima Bantuan Stimulan Perumahan Swadaya Dengan Metode AHP dan TOPSIS}

\author{
Tobias Duha ${ }^{1}$, Jan Everhard Ruwirohi ${ }^{2}$ \\ ${ }^{1}$ Akuntansi, STIE Nias Selatan \\ Nias Selatan, Indonesia \\ e-mail: bangtd@stienisel.ac.id \\ ${ }^{2}$ Sistem Komputer, Universitas Budi Luhur \\ Jakarta, Indonesia \\ e-mail: yan.everhard@budiluhur.ac.id
}

\begin{abstract}
ABSTRAK
Penentuan penerimaan bantuan stimulan perumahan swadaya (BSPS) yang dilakukan oleh Dinas Perumahan Rakyat dan Kawasan Permukiman Kabupaten Nias Selatan masih menggunakan random sampling sehingga penentuannya seringkali tidak objektif. Penulis mengusulkan metode pemilihan menggunakan sistem pendukung keputusan dengan metode AHP (Analytical Hierarchy Process) dan TOPSIS (Technique for Order Preference by Similarity to Ideal Solution). Metode AHP dan TOPSIS merupakan salah satu metode pengambilan keputusan multi kriteria dengan menerapkan bobot nilai pada setiap kriterianya. Tujuan penelitian ini untuk mempermudah Kepala Dinas Perumahan Rakyat dan Kawasan Permukiman Kabupaten Nias Selatan dan fasilitator dalam menentukan penerima bantuan rumah layak huni secara objektif. Metode AHP dan TOPSIS diaplikasikan dengan menyesuaikan hasil obeservasi dan kebutuhan Dinas Perumahan Rakyat dan Kawasan Permukiman Kabupaten Nias Selatan. Hasil penelitian ini menunjukkan penerapan metode AHP dan TOPSIS pada sistem pendukung keputusan penentuan penerima bantuan stimulan perumahan swadaya di dinas perumahan rakyat dan kawasan pemukiman Kabupaten Nias Selatan dengan nilai rata-rata 91,01\%.
\end{abstract}

Katakunci: AHP, rumah layak huni, sistem pendukung keputusan, topsis

\section{ABSTRACTS}

Determination of the acceptance of self-help housing stimulant assistance (BSPS) carried out by the public housing and settlement areas of South Nias regency still uses random sampling so that the determination is often not objective. The authors propose a selection method using Decision Support System (DSS) with AHP (Analytical Hierarchy Process) and TOPSIS (Technique for Order Preference by Similarity to Ideal Solution) method. AHP and TOPSIS methods a multi-criteria decision-making method by applying a weighted value to each criterion. The purpose of this research is to make it easier for the Head of the Department of Public Housing and Settlement Areas of South Nias Regency and facilitators in determining the recipients of housing assistance objectively. The AHP and Topsis methods are applied by adjusting on the results of observations and the needs of the Public Housing and Residential Areas of South Nias Regency. The results of this study indicate the application of the AHP and TOPSIS methods to the decision support system for determining the recipients of self-help housing stimulant assistance in the public housing service and residential areas of South Nias Regency with an average value of $91.01 \%$.

Keywords: AHP, decision support system, livable house, topsis 


\section{PENDAHULUAN}

Rumah layak huni adalah rumah yang memenuhi persyaratan keselamatan bangunan dan kecukupan minimum luas bangunan serta kesehatan penghuninya. Tempat tinggal pada dasarnya merupakan wadah bagi manusia atau keluarga dalam melangsungkan kehidupannya. Pada hakikatnya fungsi tempat tinggal bagi kehidupan manusia memang sangat vital. Tanpa tempat tinggal, manusia tidak akan dapat hidup dengan layak. Terpenuhinya kebutuhan akan pangan dan sandang saja tidaklah cukup. Ada peringkat dalam pemenuhan atas kebutuhan itu, dari kebutuhan yang minimum hingga yang tidak terbatas (M \& Marlina, 2006). Dalam artikel (Simatupang et al., 2016) menyebutkan bahwa "Rumah yang layak huni dapat diketahui dari struktur bangunan rumah dan fasilitas rumah yang ada".

Rumah tidak layak huni menurut Surat Edaran Menteri Negara Perumahan Rakyat Nomor 18/M/PR.01.03/01/2012 adalah sebagai berikut: "Rumah tidak layak huni adalah rumah yang tidak memenuhi standar layak huni yang mencakup kecukupan luas, kualitas, dan kesehatan". Dalam rangka mewujudkan hunian yang layak bagi semua orang, pemerintah bertanggungjawab untuk memberikan fasilitas kepada masyarakat agar dapat menghuni rumah yang layak dan sehat. Untuk itu, pemerintah perlu menyiapkan program-program pembangunan perumahan khususnya untuk masyarakat berpenghasilan rendah. Pemerintah Daerah memiliki peran yang penting dalam pembangunan perumahan, sebab Pemda adalah pihak yang mengetahui berapa jumlah kebutuhan hunian masyarakat.

Meskipun pembangunan perumahan yang layak sudah diarahkan agar terjangkau oleh masyarakat berpenghasilan rendah, akan tetapi sasaran ini masih belum tercapai secara menyeluruh. Dalam UU Nomor 1 Tahun 2011 Tentang Perumahan dan Kawasan Permukiman yang dimaksud dengan rumah adalah bangunan gedung yang berfungsi sebagai tempat tinggal yang layak huni, sarana pembinaan keluarga, cerminan harkat dan martabat penghuninya, serta aset bagi pemiliknya sedangkan perumahan adalah kumpulan rumah sebagai bagian dari permukiman, baik perkotaan maupun perdesaan, yang dilengkapi dengan prasarana, sarana dan utilitas umum sebagai hasil upaya pemenuhan rumah yang layak huni. Dalam rangka pemenuhan kebutuhan perumahan pemerintah melakukan usaha- usaha pembangunan rumah dengan melibatkan berbagai pihak. Usaha pemerintah ini tidak terlepas dari tujuan negara untuk menciptakan kesejahteraan rakyat. Untuk mewujudkan rumah layak huni ini, Kementerian Pekerjaan Umum dan Perumahan Rakyat melalui visi misinya tahun 2015 - 2019, sebagaimana yang tercantum di dalam Peraturan Pemerintah Nomor 165 Tahun 2014 tentang Penataan Tugas dan Fungsi Kabinet Kerja, amanat RPJMN tahap ketiga serta perubahan kondisi lingkungan strategis yang dinamis yaitu (1) Mempercepat pembangunan infrastruktur sumber daya air termasuk sumber daya maritim untuk mendukung ketahanan air, kedaulatan pangan, dan kedaulatan energi, guna menggerakkan sektor-sektor strategis ekonomi domestik dalam rangka kemandirian ekonomi; (2) Mempercepat pembangunan infrastruktur jalan untuk mendukung konektivitas guna meningkatkan produktivitas, efisiensi, dan pelayanan sistem logistik nasional bagi penguatan daya saing bangsa di lingkup global yang berfokus pada keterpaduan konektivitas daratan dan maritim; (3) Mempercepat pembangunan infrastruktur permukiman dan perumahan rakyat untuk mendukung layanan infrastruktur dasar yang layak dalam rangka mewujudkan kualitas hidup manusia Indonesia sejalan dengan prinsip 'infrastruktur untuk semua'; (4) Mempercepat pembangunan infrastruktur pekerjaan umum dan perumahan rakyat secara terpadu dari pinggiran didukung industri konstruksi yang berkualitas untuk keseimbangan pembangunan antar daerah, terutama di kawasan tertinggal, kawasan perbatasan, dan kawasan perdesaan dalam kerangka NKRI; (5) Meningkatkan tata kelola sumber daya organisasi bidang pekerjaan umum dan perumahan rakyat yang meliputi sumber daya manusia, pengendalian dan pengawasan, keikutsertaan serta penelitian dan pengembangan untuk mendukung fungsi manajemen meliputi perencanaan yang terpadu, pengorganisasian yang efisien, pelaksanaan yang tepat dan pengawasan yang ketat. Evaluasi terhadap pelaksanaan program penyediaan rumah layak huni telah dilakukan di Kabupaten Belitung yang menunjukkan bahwa program ini tepat sasaran (Winarno, 2018)

Kabupaten Nias Selatan adalah salah satu Kabupaten di Provinsi Sumatera Utara yang terdapat di Kepulauan Nias dan merupakan pusat 
kebudayaan dan adat istiadat yang hingga kini masih terpelihara. Hombo Batu atau Lompat Batu dan Tari Foluaya (Tari Perang) yang identik dengan Nias adalah merupakan kebudayaan yang hanya terdapat di Kabupaten Nias Selatan. Pada saat ini penduduk di setiap desa masih memelihara rumah adat yang menjadi tempat tinggal, tak mengherankan di setiap rumah masih terdapat berpenghuni lebih dari satu keluarga, untuk mengatasi kondisi ini pada tahun 2019, Kabupaten Nias Selatan berdasarkan informasi dari Kepala Dinas Perumahan Rakyat dan Kawasan Permukiman, mendapatkan jatah Bantuan Stimulan Perumahan Swadaya (BSPS) sebanyak 160 unit. Akan tetapi dalam penentuan calon penerima BSPS oleh tim identifikasi di lapangan dalam hal ini Tenaga Fasilitator Lapangan khususnya dalam penilaian layak tidaknya calon penerima dilakukan dengan cara memberikan nilai pada kriteria calon penerima tidak memiliki standar yang akurat dan cenderung tidak objektif.

Penggunakan sistem pendukung keputusan dalam penentuan penerima bantuan stimulan perumahan swadaya telah dilakukan oleh (Sefrika, 2019) yang menghasilkan nilai preferensi alternatif sebanyak 0,54 dengan kriteria $\mathrm{C} 1$ yaitu tingkat kemiskinan.

Sistem pendukung keputusan dapat membantu dalam mengambil keputusan secara objektif. Banyak peneliti yang mengaplikasikan untuk menentukan penerima berbagai bantuan dari pemerintah, salah satunya dalam penentuan penerima bantuan keluarga harapan khusus lansia menggunakan metode vikor (Pardede et al., 2018) dan (Saputra \& Januarsyah, 2016) yang menerapkan metode fuzzy database model tahani dalam sistem pendukung keputusan penerima bantuan sosial.

Metode AHP - topsis sudah banyak digunakan dalam sistem pendukung keputusan, diantaranya pada penelitian yang dilakukan oleh (Sari et al., 2018) untuk rekomendasi kelulusan sidang skripsi yang menghasilkan akurasi berdasarkan jarak Hamming sebesar 96,2\% dan jarak Euclidean 0,8096. Metode AHP juga digunakan oleh (Rahardian et al., 2018) dalam menentukan penerima bantuan keluarga miskin. (Munthafa \& Mubarok, 2017) menerapkan metode AHP untuk menentukan mahasiswa berprestasi yang menghasilkan rekomendasi alternatif dengan nilai indeks konsisten sebesar 0,06 . Metode AHP juga digunakan untuk pemilihan supplier (Nurmalasari \& Pratama, 2018). Beberapa peneliti juga menggabung metode AHP dengan metode lain seperti pada penelitiannya (Diah et al., 2018) yang menerapkan metode AHP - SAW dalam menentukan kenaikan jabatan karyawan. Dalam penelitian (Wulandari, 2017) menggabungkan metode AHP dengan Promethee untuk pemilihan supplier.

\section{METODE PENELITIAN}

Metode penelitian yang diterapkan pada penelitian ini melalui tiga tahapan, yaitu:

1) Tahapan Pengumpulan Data

Pada tahapan ini menjelaskan mengenai cara pengumpulan data yang dilakukan dalam penelitian. Tahapan pada pengumpulan data yaitu studi pustaka, observasi, wawancara dan kuesioner.

2) Tahapan Pemahaman Data

Pada tahapan ini menjelaskan mengenai metode AHP dan TOPSIS. Proses pada tahapan ini yaitu pemahaman data dan proses persiapan data. Pada pemahaman data ada beberapa hal yang dilakukan antara lain, mengumpulkan data awal, mendeskripsikan data, mengeksplorasi data, dan memverifikasi kualitas data.

3) Persiapan Data

Pada tahapan ini menjelaskan mengenai pemodelan dan evaluasi. Pada tahapan ini ada beberapa hal yang dilakukan antara lain, deskripsi data set, memilih data, membangun data, mengintegrasikan data, dan membersihkan data. Dilakukan berdasarkan hasil dari penelitian.

Teknik analisis data adalah tahapan awal berdasarkan data-data yang telah dikumpulkan melalui tahapan wawancara, observasi dan studi pustaka untuk mendapatkan kebutuhankebutuhan sistem yang akan digunakan dalam pemecahan masalah yang tepat. Tahapantahapan dalam sistem siklus pengembangan sistem, yaitu:

1) Perencanaan sistem, pada tahap ini mengumpulkan data pada sistem yang berjalan.

2) Menganalisa sistem, pada tahap ini dilakukan survei observasi ke sistem yang ada, sehingga dapat dirumuskan informasi apa saja yang dibutuhkan dan diperlukan sistem.

3) Merancang secara konseptual, pada tahap ini dilakukan evaluasi terhadap berbagai alternatif dan menyiapkan spesifikasi perancangan yang sesuai dengan permintaan dan kebutuhan sistem. 
4) Implementasi sistem, pada tahap ini dilakukan penerapan software yang telah selesai.

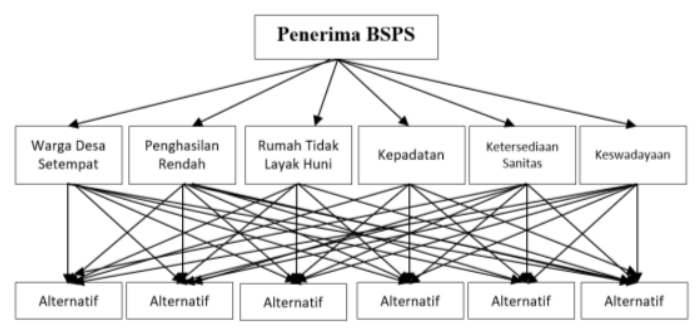

Gambar 1. Teknik Analisis Metode AHP Penerima BSPS

Terdapat tiga prinsip utama dalam pemecahan masalah dalam AHP (Analytical Hierachy Process), yaitu Decomposition, Comparative Judgement dan Logical Concistency. Secara garis besar prosedur AHP (Analitical Hieracrchy Process) meliputi tahapan sebagai berikut:

1) Dekomposisi masalah;

2) Penilaian/Pembobotan untuk membandingkan elemen-elemen;

3) Penyusunan matriks dan uji konsistensi;

4) Penetapan prioritas pada masing-masing hirarki;

5) Sintensis dari prioritas; dan

6) Pengambilan/pemetaan keputusan.

\section{HASIL DAN PEMBAHASAN}

Pada penelitian ini, penerimaan bantuan stimulan perumahan swadaya (BSPS) menggunakan perangkingan dengan cara melakukan wawancara dengan orang yang berkompeten di kegiatan diklat kepemimpinan. Dari hasil wawancara dan panduan rancangan proyek perubahan, maka ditetapkan kriteriakriteria seperti dapat dilihat pada tabel 1.

Tabel 1. Kriteria Calon Penerima BSPS

\begin{tabular}{cl}
\hline Kode & Kriteria BSPS \\
\hline K1 & Warga Desa Setempat \\
K2 & Berpenghasilan Rendah \\
K3 & Rumah Tidak Layak Huni \\
K4 & Kepadatan \\
K5 & Ketersediaan Sanitasi \\
K6 & Keswadayaan \\
\hline
\end{tabular}

Berdasarkan tabel 1, penerima BSPS harus warga desa setempat dengan dibuktikan KTP dan KK. Calon penerima berpenghasilan rendah, dalam artian mempunyai penghasilan namun tidak cukup untuk membangun atau merenovasi rumah yang ditepati menjadi rumah layak huni. Penghasilan ini minimal Rp. 1.000 .000 (satu juta rupiah) sesuai standar UMK Kabupaten Nias Selatan dan dibuktikan dengan surat pernyataan berpenghasilan yang diketahui oleh Kepala Desa setempat. Calon penerima mempunyai tempat tinggal namun tidak layak huni dapat dilihat dari kondisi rumahnya berupa lantai minimal semen, dinding papan dan atap rumah dari daun rumbia. Calon penerima BSPS mempunyai tempat tinggal namun dihuni lebih dari satu keluarga. Calon penerima bersedia untuk dibuatkan sanitasi (jika tidak ada) supaya rumah tersebut menjadi rumah sehat. Calon penerima harus mampu membentuk swadaya untuk bisa membangun sebuah rumah layak huni yang beranggotakan minimal 20 orang yang berasal dari desa setempat.

Setelah menentukan kriteria calon penerima BSPS, tahap selanjutnya yaitu memberikan penilaian terhadap calon penerima BSPS berdasarkan kriteria yang telah ditetapkan. Bagi masyarakat yang memiliki nilai tertinggi maka berhak untuk mendapatkan BSPS.

\subsection{Perhitungan Bobot Kriteria Penentuan BSPS}

Proses perhitungan AHP dilakukan untuk mendapatkan nilai bobot prioritas dari kriteriakriteria yang telah ditentukan, dengan cara pengisian kuesioner oleh pakar. Untuk menghasilkan sebuah bobot prioritas yang objektif maka kuesioner dilakukan lebih kepada satu orang. Detail kuesioner penentuan penerima BSPS dijabarkan pada tabel 2 - tabel 6 .

Tabel 2. Penilaian Pakar Ir. Yudika Duha

\begin{tabular}{ccccccc}
\hline $\begin{array}{c}\text { Kriteria } \\
\text { BSPS }\end{array}$ & K1 & K2 & K3 & K4 & K5 & K6 \\
\hline K1 & 1,00 & 3,00 & 0,33 & 0,14 & 0,20 & 0,33 \\
K2 & 0,33 & 1,00 & 0,11 & 0,33 & 0,33 & 0,33 \\
K3 & 3,00 & 9,00 & 1,00 & 0,33 & 3,00 & 0,33 \\
K4 & 7,00 & 3,00 & 3,00 & 1,00 & 3,00 & 0,11 \\
K5 & 5,00 & 3,00 & 0,33 & 0,33 & 1,00 & 0,33 \\
K6 & 3,00 & 3,00 & 3,00 & 9,00 & 3,00 & 1,00 \\
\hline
\end{tabular}

Tabel 3. Penilaian Pakar Ferdianto Duha, SE

\begin{tabular}{ccccccc}
$\begin{array}{c}\text { Kriteria } \\
\text { BSPS }\end{array}$ & K1 & K2 & K3 & K4 & K5 & K6 \\
\hline K1 & 1,00 & 3,00 & 0,33 & 0,20 & 0,33 & 0,33 \\
K2 & 0,33 & 1,00 & 0,33 & 0,33 & 0,33 & 0,33 \\
K3 & 3,00 & 3,00 & 1,00 & 0,33 & 0,33 & 0,33 \\
K4 & 5,00 & 3,00 & 3,00 & 1,00 & 0,33 & 0,20 \\
K5 & 3,00 & 3,00 & 3,00 & 3,00 & 1,00 & 0,33 \\
K6 & 3,00 & 3,00 & 3,00 & 5,00 & 3,00 & 1,00 \\
\hline
\end{tabular}


Tabel 4. Penilaian Pakar Gayusbin Duha, SE

\begin{tabular}{ccccccc}
\hline $\begin{array}{c}\text { Kriteria } \\
\text { BSPS }\end{array}$ & K1 & K2 & K3 & K4 & K5 & K6 \\
\hline K1 & 1,00 & 3,00 & 0,33 & 0,33 & 0,33 & 0,14 \\
K2 & 0,33 & 1,00 & 3,00 & 0,33 & 0,33 & 0,33 \\
K3 & 3,00 & 0,33 & 1,00 & 0,33 & 3,00 & 0,33 \\
K4 & 3,00 & 3,00 & 3,00 & 1,00 & 3,00 & 5,00 \\
K5 & 3,00 & 3,00 & 0,33 & 0,33 & 1,00 & 0,33 \\
K6 & 7,00 & 3,00 & 3,00 & 0,20 & 3,00 & 1,00 \\
\hline
\end{tabular}

Tabel 5. Penilaian Pakar Agripa Daya

\begin{tabular}{ccccccc}
\hline $\begin{array}{c}\text { Kriteria } \\
\text { BSPS }\end{array}$ & K1 & K2 & K3 & K4 & K5 & K6 \\
\hline K1 & 1,00 & 3,00 & 0,33 & 0,20 & 0,33 & 0,33 \\
K2 & 0,33 & 1,00 & 0,20 & 0,11 & 0,33 & 0,20 \\
K3 & 3,00 & 3,00 & 1,00 & 0,33 & 0,33 & 0,33 \\
K4 & 5,00 & 3,00 & 3,00 & 1,00 & 0,33 & 0,33 \\
K5 & 3,00 & 3,00 & 3,00 & 3,00 & 1,00 & 3,00 \\
K6 & 3,00 & 5,00 & 3,00 & 3,00 & 0,33 & 1,00 \\
\hline
\end{tabular}

Tabel 6. Penilaian Pakar Nasrani Gari

\begin{tabular}{ccccccc}
\hline $\begin{array}{c}\text { Kriteria } \\
\text { BSPS }\end{array}$ & K1 & K2 & K3 & K4 & K5 & K6 \\
\hline K1 & 1,00 & 0,33 & 0,33 & 0,33 & 0,33 & 0,20 \\
K2 & 3,00 & 1,00 & 0,33 & 0,33 & 0,33 & 0,20 \\
K3 & 3,00 & 3,00 & 1,00 & 0,20 & 0,33 & 0,33 \\
K4 & 3,00 & 3,00 & 3,00 & 1,00 & 0,33 & 0,33 \\
K5 & 3,00 & 3,00 & 3,00 & 3,00 & 1,00 & 0,33 \\
K6 & 5,00 & 5,00 & 3,00 & 3,00 & 3,00 & 1,00 \\
\hline
\end{tabular}

Setelah hasil kuesioner diperoleh, tahap selanjutnya mencari rata-rata geometrik bobot penilaian dari beberapa responden dalam suatu kelompok dirata- ratakan dengan rata-rata geometrik penilaian (Geometric Mean).
Tujuannya adalah untuk mendapatkan suatu nilai tunggal yang mewakili sejumlah responden. Rumus rata - rata geometric adalah sebagai berikut:

\begin{tabular}{|c|c|c|c|c|c|c|}
\hline \multirow{2}{*}{\multicolumn{7}{|c|}{$\mathrm{G}=\sqrt[n]{x 1 \cdot x 2 \ldots x n}$}} \\
\hline & & & & & & \\
\hline \multicolumn{7}{|c|}{$\mathrm{G}=$ rata - rata Geometrik } \\
\hline \multicolumn{7}{|c|}{$\mathrm{Xn}=$ Penilaian ke $1,2,3 \ldots \mathrm{n}$} \\
\hline \multicolumn{7}{|c|}{$\mathrm{N}=$ Jumlah Penilaian } \\
\hline \multicolumn{7}{|c|}{$0,517=\sqrt[5]{0,33 \times 0,33 \times 0,33 \times 0,33 \times 0,33}$} \\
\hline \multicolumn{7}{|c|}{$3,000=\sqrt[5]{3,00 \times 3,00 \times 3,00 \times 3,00 \times 3,00}$} \\
\hline \multicolumn{7}{|c|}{$4,360=\sqrt[5]{7,00 \times 5,00 \times 3,00 \times 5,00 \times 3,00}$} \\
\hline \multicolumn{7}{|c|}{$3,323=\sqrt[5]{5,00 \times 3,00 \times 3,00 \times 3,00 \times 3,00}$} \\
\hline \multicolumn{7}{|c|}{$3,936=\sqrt[5]{3,00 \times 3,00 \times 7,00 \times 3,00 \times 5,00}$} \\
\hline \multicolumn{7}{|c|}{ Tabel 7. Geometrik Penilaian Responden } \\
\hline $\begin{array}{c}\text { Kriteria } \\
\text { BSPS }\end{array}$ & $\mathrm{K} 1$ & K2 & K3 & K4 & $\mathrm{K} 5$ & K6 \\
\hline K1 & 1,000 & 1,933 & 0,333 & 0,229 & 0,301 & 0,254 \\
\hline K2 & 0,517 & 1,000 & 0,375 & 0,268 & 0,333 & 0,272 \\
\hline K3 & 3,000 & 2,408 & 1,000 & 0,301 & 0,803 & 0,333 \\
\hline K4 & 4,360 & 3,000 & 3,000 & 1,000 & 0,803 & 0,415 \\
\hline K5 & 3,323 & 3,000 & 1,246 & 1,246 & 1,000 & 0,517 \\
\hline $\mathrm{K} 6$ & 3,936 & 3,680 & 3,000 & 2,408 & 1,933 & 1,000 \\
\hline Imlah & 16,136 & 15,022 & 8,954 & 5,452 & 5,173 & $\begin{array}{l}2,792 \\
\end{array}$ \\
\hline
\end{tabular}

Menghitung total setiap kolom pada baris kriteria K1 sampai K6

$$
\begin{aligned}
& 1,000+0,517+3,000+4,360+3,323+3,936 \\
& =16,136 \\
& 1,933+1,000+2,408+3,000+3,000+3,680 \\
& =15,022 \\
& 0,333+0,375+1,000+3,000+1,246+3,000 \\
& =8,954 \\
& 0,229+0,268+0,301+1,000+3,246+2,408 \\
& =5,452 \\
& 0,301+0,333+0,803+0,803+1,000+1,933 \\
& =5,173 \\
& 0,254+0,272+0,333+0,415+0,517+ \\
& 1,000=2,791
\end{aligned}
$$

Tabel 8. Prioritas Penilaian Perbandingan Berpasangan

\begin{tabular}{cccccccc}
\hline Kriteria BSPS & K1 & K2 & K3 & K4 & K5 & K6 & Bobot Prioritas \\
\hline K1 & 0,062 & 0,129 & 0,037 & 0,042 & 0,058 & 0,091 & 0,070 \\
K2 & 0,032 & 0,067 & 0,042 & 0,049 & 0,064 & 0,097 & 0,059 \\
K3 & 0,186 & 0,160 & 0,112 & 0,055 & 0,155 & 0,119 & 0,131 \\
K4 & 0,270 & 0,200 & 0,335 & 0,183 & 0,155 & 0,149 & 0,215 \\
K5 & 0,206 & 0,200 & 0,139 & 0,228 & 0,193 & 0,185 & 0,192 \\
K6 & 0,244 & 0,245 & 0,335 & 0,442 & 0,374 & 0,358 & 0,333 \\
\hline Jumlah & 1,000 & 1,000 & 1,000 & 1,000 & 1,000 & 1,000 & 1,000 \\
\hline
\end{tabular}

Hasil dari nilai responden kriteria di bagi dengan nilai jumlah total responden dari hasil geometric nilai berpasangan.

$$
\frac{1,000}{16,136}=0,062
$$

$$
\begin{aligned}
& \frac{0,517}{16,136}=0,032 \\
& \frac{3,000}{16,136}=0,186 \\
& \frac{4,360}{16,136}=0,270
\end{aligned}
$$




$$
\begin{aligned}
& \frac{3,323}{16,136}=0,206 \\
& \frac{3,936}{16,136}=0,244
\end{aligned}
$$

Selanjutnya menjumlahkan setiap nilai kriteria pada baris pertama K1 sampai pada baris K6 untuk mendapatkan nilai bobot prioritas.

$$
\begin{aligned}
& 0,062+0,129+0,037+0,042+0,058+0,031 \\
& =0,070 \\
& 0,032+0,067+0,042+0,049+0,064+0,097 \\
& =0,059 \\
& 0,186+0,160+0,112+0,055+0,155+0,119 \\
& =0,131 \\
& 0,270+0,200+0,335+0,183+0,155+0,149 \\
& =0,215 \\
& 0,206+0,200+0,139+0,228+0,193+0,185 \\
& =0,192 \\
& 0,244+0,245+0,335+0,422+0,374+0,169 \\
& =0,333
\end{aligned}
$$

\subsection{Uji Konsistensi Matrik}

Perhitungan uji konsistensi matrik untuk mendapatkan nilai vektor A dengan cara nilai dari geometrik respoonden dikalikan dengan nilai bobot yang sudah didapatkan.

Selanjutnya nilai vektor eign dikalikan dengan matriks semua menghasilkan nilai baris, yang selanjutnya setiap nilai dibagi kembali dengan nilai vector yang bersangkutan. Nilai ratarata dari hasil pembagian ini merupakan Principal Eign Value Maximum ( $\left.\lambda_{\max }\right)$

$\left[\begin{array}{llllll}1,000 & 1,933 & 0,333 & 0,229 & 0,301 & 1,254 \\ 0,517 & 1,000 & 0,375 & 0,268 & 0,333 & 0,272 \\ 3,000 & 2,408 & 1,000 & 0,301 & 0,803 & 0,333 \\ 4,360 & 3,000 & 3,000 & 1,000 & 0,803 & 0,415 \\ 3,323 & 3,000 & 1,246 & 1,246 & 1,000 & 0,517 \\ 3,936 & 3,680 & 3,000 & 2,408 & 1,933 & 1,000\end{array}\right] \times\left[\begin{array}{l}0,070 \\ 0,059 \\ 0,131 \\ 0,215 \\ 0,192 \\ 0,333\end{array}\right]$

$$
=\left[\begin{array}{l}
0,419 \\
0,495 \\
0,812 \\
1,382 \\
1,204 \\
2,107
\end{array}\right]
$$

Consistency Vector

$\left[\begin{array}{l}0,070 \\ 0,059 \\ 0,131 \\ 0,215 \\ 0,192 \\ 0,333\end{array}\right]:\left[\begin{array}{l}0,419 \\ 0,495 \\ 0,812 \\ 1,382 \\ 1,204 \\ 2,107\end{array}\right]=\left[\begin{array}{l}5,992 \\ 8,455 \\ 6,183 \\ 6,416 \\ 6,271 \\ 6,329\end{array}\right]$

$$
\begin{aligned}
(\lambda \max )=\frac{(5,992+8,455+6,183+6,416+6,271+6,392)}{6} & \\
= & 6,608 \\
\text { Selanjutnya } & \text { mencari nilai index }
\end{aligned}
$$
konsistensi $(\mathrm{Cl})$ yang di peroleh:

$$
\mathrm{CI}=\frac{(6,608-6)}{(6-1)}=0,122
$$

Selanjutnya mencari nilai Consistency Ratio, Dengan $\mathrm{n}=6, \mathrm{RI}=1,24$, maka :

$$
\mathrm{CR}=\frac{0,122}{1,24}=0,098
$$

Karena $C R<0,100$ berarti preferensi responden adalah konsisten.

\subsection{Penentuan Ranking Penerima BSPS Metode TOPSIS}

Setelah mendapatkan nilai eign kriteria dari nilai elgen alternatif. Kemudian dilanjutkan dengan perhitungan topsis. Matriks keputusan yang dihasilkan dari metode AHP merupakan modal awal dalam perhitungan topsis. Matriks bobot alternatif terhadap kriteria merupakan matriks ternormalisasi pada metode topsis. Berikut langkah perhitungan SPK metode topsis.

1) Data alternatif sebagai orang/objek yang akan dinilai. Data alternatif terdiri dari kode dan nama penerima.

Tabel 9. Data Alternatif Calon Penerima BSPS

\begin{tabular}{cl}
\hline \multicolumn{1}{c}{ NIK } & \multicolumn{1}{c}{ Nama Penerima } \\
\hline 1214060304750002 & Khouzisokhi Duha \\
1214064902940007 & Anandrozisokhi Duha \\
1214060303810004 & Faabolo Duha \\
1214061904840002 & Sukardin Gowasa \\
1214065302680002 & Hatiami Duha \\
1214061506690002 & Ndrohuzisokhi Duha \\
1214060608780009 & Dehezisokhi Gaurifa \\
1214062105880004 & Paskah Gaurifa \\
1214065601960003 & Felernia Duha \\
1214065102820001 & Surina Gaurifa \\
1214044212720001 & Masihati Duha \\
1214060407630002 & Faambo Gaurifa \\
1214066912910003 & Hakhositodo Bazikho \\
\hline
\end{tabular}

2) Data kriteria sebagai dasar penilaian untuk alternatif. Kriteria bisa berupa cost atau benefit. Benefit berarti semakin besar nilainya semakin bagus, sebaliknya cost semakin kecil nilainya, terdapat atribut tambahan yaitu bobot kriteria. Bobot ini untuk menentukan kriteria mana yang lebih diutamakan. Semakin besar bobot, maka semakin diutamakan kriteria tersebut semakin bagus seperti terlihat pada tabel 10 .

Tabel 10. Bobot Kriteria

\begin{tabular}{clcc}
\hline Kode & Nama Kriteria & Atribut & Bobot \\
\hline K1 & Warga Desa Setempat & Benefit & 0,070 \\
K2 & Penghasilan Rendah & Cost & 0,059 \\
K3 & Rumah Tidak Layak Huni & Benefit & 0,131 \\
K4 & Kepadatan & Benefit & 0,215 \\
K5 & Ketersediaan Sanitasi & Benefit & 0,192 \\
K6 & Keswadayaan & Cost & 0,333 \\
\hline
\end{tabular}


3) Nilai alternatif ini didapat dari berita acara penilaian calon penerima BSPS yang telah dinilai oleh tenaga fasilitator lapangan dan di ketahui oleh Kepala Dinas Perumahan Rakyat dan Kawasan Permukiman Kabupaaten Nias Selatan. Untuk mempermudah biasanya ditampilkan dalam bentuk tabel (matriks) dengan alternatif sebagai judul baris dan kriteria sebagai judul kolom. Setiap alternatif harus mempunyai nilai pada semua kriteria walaupun nilainya 0 (nol) seperti terlihat pada tabel 11.

Tabel 11. Matriks Normalisasi

\begin{tabular}{lllllll}
\hline alternatif & K1 & K2 & K3 & K4 & K5 & K6 \\
\hline 1214060304750002 & 89 & 88 & 90 & 75 & 88 & 90 \\
1214064902940007 & 86 & 87 & 88 & 82 & 80 & 79 \\
1214060303810004 & 80 & 75 & 80 & 81 & 70 & 90 \\
1214061904840002 & 90 & 75 & 70 & 75 & 88 & 90 \\
1214065302680002 & 85 & 89 & 89 & 89 & 90 & 88 \\
1214061506690002 & 90 & 69 & 88 & 75 & 90 & 90 \\
1214060608780009 & 83 & 90 & 85 & 86 & 79 & 84 \\
1214062105880004 & 84 & 84 & 90 & 90 & 82 & 86 \\
1214065601960003 & 88 & 90 & 90 & 89 & 90 & 83 \\
1214065102820001 & 90 & 90 & 88 & 85 & 86 & 71 \\
1214044212720001 & 90 & 88 & 89 & 87 & 89 & 69 \\
1214060407630002 & 90 & 75 & 88 & 88 & 90 & 89 \\
1214066912910003 & 90 & 71 & 75 & 90 & 89 & 75 \\
\hline
\end{tabular}

Nilai pada tabel didapatkan dari hasil pengamatan tenaga fasilitator lapangan terhadap calon penerima BSPS, adapun ketentuan pemberian nilai pada Rumah Tidak Layak Huni (RTLH) berdasarkan petunjuk/pedoman skor penilaian yang di keluarkan oleh Kepala Dinas Perumahan Rakyat dan Kawasan Permukiman Kabupaten Nias Selatan:

a. Warga Desa Setempat, apabila keluarga tersebut, dalam satu rumah dihuni lebih dari satu keluarga maka penilaian diberikan:

- Satu keluarga 69-79
- Lebih dari tiga keluarga $80-85$

- Lebih dari empat keluarga 86-90

b. Penghasilan Rendah, apabila keluarga tersebut memilki pengeluaran rata-rata:

- Pengeluaran perbulan antara Rp. 200.000 $-400.000=69-79$

- Pengeluaran perbulan antara Rp. 500.000 $-700.000=80-85$

- Pengeluaran perbulan antara Rp. 800.000 $-900.000=86-90$

c. Rumah Tidak Layak Huni

- Lantai semen rusak parah, dinding papan dan atap daun rumbia $86-90$

- Lantai semen rusak parah, dinding setengah beton dan atap rumbia $76-85$

- Lantai semen masih utuh, dinding setengah beton dan atap seng $69-75$

d. Kepadatan

- Luas bangunan $5 \mathrm{~m} \times 10 \mathrm{~m}=69-79$

- Luas bangunan $5 \mathrm{~m} \times 8 \mathrm{~m}=80-90$

e. Ketersediaan Sanitasi

- Sanitasi kondisi baik, ketersediaan air dan saluran pembuangan : $86-90$

- Sanitasi kondisi baik, ketersediaan air tidak ada (menggunakan air hujan) $79-85$

f. Keswadayaan

- Beranggotakan 20 orang dari desa setempat $80-90$

- Beranggotakan sebagian dari penduduk desa tetangga yang berdekatan 70 - 79

Untuk melakukan normalisasi kita harus mengkuadratkan setiap elemen matriks, contoh pada kolom K1 $(89 \times 89=7921),(86 \times 86=736)$, $(80 \times 80=6400), \quad(90 \times 90=8100), \quad(83 \times 83=7225)$, $(84 \times 84=8100)$, dan seterusnya sampai pada kolom K6, setelah itu di jumlah dan total penjumlahan dikudratkan, seperti pada tabel 12 .

Tabel 12. Normalisasi

\begin{tabular}{|c|c|c|c|c|c|c|}
\hline Alternatif & K1 & K2 & K3 & K4 & K5 & K6 \\
\hline 1214060304750002 & 7921 & 7744 & 8100 & 5625 & 7744 & 8100 \\
\hline 1214064902940007 & 7396 & 7569 & 7744 & 6724 & 6400 & 6241 \\
\hline 1214060303810004 & 6400 & 5625 & 6400 & 6561 & 4900 & 8100 \\
\hline 1214061904840002 & 8100 & 5625 & 4900 & 5625 & 7744 & 8100 \\
\hline 1214065302680002 & 7225 & 7921 & 7921 & 7921 & 8100 & 7744 \\
\hline 1214061506690002 & 8100 & 4761 & 7744 & 5625 & 8100 & 8100 \\
\hline 1214060608780009 & 6889 & 8100 & 7225 & 7396 & 6241 & 7056 \\
\hline 1214062105880004 & 7056 & 7056 & 8100 & 8100 & 6724 & 7396 \\
\hline 1214065601960003 & 7744 & 8100 & 8100 & 7921 & 8100 & 6889 \\
\hline 1214065102820001 & 8100 & 8100 & 7744 & 7225 & 7396 & 5041 \\
\hline 1214044212720001 & 8100 & 7744 & 7921 & 7569 & 7921 & 4761 \\
\hline 1214060407630002 & 8100 & 5625 & 7744 & 7744 & 8100 & 7921 \\
\hline 1214066912910003 & 8100 & 5041 & 5625 & 8100 & 7921 & 5625 \\
\hline Total & 99231 & 89011 & 95268 & 92136 & 95391 & 91074 \\
\hline Akar (sqrt) & 315,010 & 298,347 & 308,655 & 303,539 & 308,854 & 301,785 \\
\hline
\end{tabular}


4) Normalisasi Matriks Terbobot

Normalisasi matriks terbobot didapat dari tabel nilai alternatif dibagi dengan dengan hasil dari pada akar tabel 12, seperti terlihat pada tabel 13.

Tabel 13. Matriks Terbobot

\begin{tabular}{lcccccc}
\hline Alternatif & K1 & K2 & K3 & K4 & K5 & K6 \\
\hline 1214060304750002 & 0,283 & 0,295 & 0,292 & 0,247 & 0,285 & 0,298 \\
1214064902940007 & 0,273 & 0,292 & 0,285 & 0,270 & 0,259 & 0,262 \\
1214060303810004 & 0,254 & 0,251 & 0,259 & 0,267 & 0,227 & 0,298 \\
1214061904840002 & 0,286 & 0,251 & 0,227 & 0,247 & 0,285 & 0,298 \\
1214065302680002 & 0,270 & 0,298 & 0,288 & 0,293 & 0,291 & 0,292 \\
1214061506690002 & 0,286 & 0,231 & 0,285 & 0,247 & 0,291 & 0,298 \\
1214060608780009 & 0,263 & 0,302 & 0,275 & 0,283 & 0,256 & 0,278 \\
1214062105880004 & 0,267 & 0,282 & 0,292 & 0,297 & 0,265 & 0,285 \\
1214065601960003 & 0,279 & 0,302 & 0,292 & 0,293 & 0,291 & 0,275 \\
1214065102820001 & 0,286 & 0,302 & 0,285 & 0,280 & 0,278 & 0,235 \\
1214044212720001 & 0,286 & 0,295 & 0,288 & 0,287 & 0,288 & 0,229 \\
1214060407630002 & 0,286 & 0,251 & 0,285 & 0,290 & 0,291 & 0,295 \\
1214066912910003 & 0,286 & 0,238 & 0,243 & 0,297 & 0,288 & 0,249 \\
\hline
\end{tabular}

Contoh pada kolom baris pertama: $(89 / 315,010=0,283),(88 / 298,347=$ $0,295)(90 / 308,655=0,292),(75 / 303,539=$ $0,247),(88 / 308,854=0,285),(90 / 301,785=$ $0,298)$ sampai seterusnya pada kolom terakhir.

Tabel 14. Bobot Prioritas AHP

\begin{tabular}{llllll}
\hline K1 & K2 & K3 & K4 & K5 & K6 \\
\hline 0,070 & 0,059 & 0,131 & 0,215 & 0,195 & 0,333 \\
\hline \multicolumn{7}{c}{ Mencari Bobot Prioritas (Vektor Eigen) }
\end{tabular}

Vektor Eigen $=\sum$ Kriteria $/ n$

$\frac{(0,062+0,129+0,037+0,042+0,058+0,091)}{6}$
$=\mathbf{0 , 0 7 0}$
$\frac{(0,032+0,067+0,042+0,049+0,064+0,097)}{6}$
$=\mathbf{0 , 0 5 9}$

$$
\begin{gathered}
\frac{(0,186+0,160+0,112+0,055+0,155+0,119)}{6} \\
=\mathbf{0}, \mathbf{1 3 1} \\
\frac{(0,270+0,200+0,335+0,183+0,155+0,149)}{6} \\
=\mathbf{0 , 2 1 5} \\
\frac{(0,206+0,200+0,139+0,228+0,193+0,185)}{6} \\
=\mathbf{0 , 1 9 5} \\
\frac{(0,244+0,245+0,335+0,442+0,374+0,358)}{6} \\
=\mathbf{0 , 3 3 3}
\end{gathered}
$$

5) Normalisasi Terbobot

Normalisasi terbobot didapatkan dari perkalian pada matriks normalisasi dengan bobot kriteria, seperti pada tabel 15.

Tabel 15. Normalisasi Terbobot

\begin{tabular}{ccccccc}
\hline Alternatif & K1 & K2 & K3 & K4 & K5 & K6 \\
\hline 1214060304750002 & 0,029 & 0,018 & 0,044 & 0,055 & 0,074 & 0,061 \\
1214064902940007 & 0,028 & 0,018 & 0,043 & 0,061 & 0,067 & 0,054 \\
1214060303810004 & 0,026 & 0,016 & 0,039 & 0,060 & 0,058 & 0,061 \\
1214061904840002 & 0,030 & 0,016 & 0,034 & 0,055 & 0,074 & 0,061 \\
1214065302680002 & 0,028 & 0,018 & 0,044 & 0,066 & 0,075 & 0,060 \\
1214061506690002 & 0,030 & 0,014 & 0,043 & 0,055 & 0,075 & 0,061 \\
1214060608780009 & 0,027 & 0,019 & 0,042 & 0,063 & 0,066 & 0,057 \\
1214062105880004 & 0,028 & 0,017 & 0,044 & 0,066 & 0,068 & 0,059 \\
1214065601960003 & 0,029 & 0,019 & 0,044 & 0,066 & 0,075 & 0,057 \\
1214065102820001 & 0,030 & 0,019 & 0,043 & 0,063 & 0,072 & 0,048 \\
1214044212720001 & 0,030 & 0,018 & 0,044 & 0,064 & 0,074 & 0,047 \\
1214060407630002 & 0,030 & 0,016 & 0,043 & 0,065 & 0,075 & 0,061 \\
1214066912910003 & 0,030 & 0,015 & 0,037 & 0,066 & 0,074 & 0,051 \\
\hline
\end{tabular}


Baris Pertama $=$

$(0,238 * 0,104=0,029), \quad(0,295 * 0,062=0,018)$,

$(0,292 * 0,151=0,044), \quad(0,247 * 0,224=0,055)$,

$(0,285 * 0,258=0,258),(0,298 * 0,206=0,061)$

Baris Kedua $=$

$(0,273 * 0104=0,028), \quad(0,292 * 0,062=0,018)$,

$(0,285 * 0,151=0,043), \quad(0,270 * 0,224=0,061)$,

$(0,259 * 0,258=0,067),(0,262 * 0,206=0,054)$,

Baris Ketiga $=$

$(0,254 * 0104=0,026), \quad(0,251 * 0,062=0,016)$,

$(0,259 * 0,151=0,039), \quad(0,267 * 0,224=0,060)$,

$(0,259 * 0,227=0,058),(0,298 * 0,206=0,061)$,

Baris Keempat $=$

$(0,286 * 0104=0,030), \quad(0,251 * 0,062=0,016)$

$(0,227 * 0,151=0,034), \quad(0,247 * 0,247=0,055)$,

$(0,285 * 0,227=0,074),(0,298 * 0,206=0,061)$,

dan seterusnya sampai pada baris terakhir.

6) Matriks Solusi Ideal

Dari matriks keputusan ternormalisasi pada tabel 15 , dapat ditentukan titik ideal positif dan titik ideal negatif dengan titik ideal positif dan titik ideal negatif.

Tabel 16. Matriks Solusi Ideal

\begin{tabular}{lcccccc}
\hline $\begin{array}{c}\text { Titik } \\
\text { Ideal }\end{array}$ & K1 & K2 & K3 & K4 & K5 & K6 \\
\hline $\begin{array}{l}\text { Positif } \\
\text { Negatif }\end{array}$ & 0,020 & 0,018 & 0,038 & 0,064 & 0,056 & 0,099 \\
\hline
\end{tabular}

Perhitungan solusi ideal positif menggunakan rumus:

$$
A_{i^{+}}=\sqrt{\sum_{j}^{n}=1}\left(y_{i j}-y^{+} i\right)^{2}
$$

Dan perhitungan solusi ideal negatif menggunakan rumus:

$$
A_{i^{-}}=\sqrt{\sum_{j}^{n}=1}\left(y_{i j}-y^{+} i\right)^{2}
$$

Setelah didapat titik ideal positif dan titik ideal negatif terdapat kriteria dan nilai eigen kriteria lalu tentukan jarak setiap alternatif terhadap titik ideal positif dan negatif.

7) Menentukan jarak antara nilai setiap alternatif dengan solusi ideal positif dan solusi ideal negatif. Untuk mencari total dan perangkingan, kita harus mencari jara solusi ideal positif dan negatif yang didapat dari pengolahan tabel 15 (normalisasi terbobot) dan tabel 16 (matriks solusi ideal) caranya adalah mengkuadratkan selisih setiap elemen matriks normalisasi terbobot dengan matriks solusi ideal, kemudian menjumlahkan setiap alternatif setelah diakarkan.

Tabel 17. Jarak Solusi Ideal Positif dan Solusi

\begin{tabular}{ccccc}
\multicolumn{5}{c}{ Ideal Negatif } \\
\hline Alternatif & Positif & Negatif & Prefensi & Ranking \\
\hline 1214060304750002 & 0,011 & 0,023 & 0,676 & 5 \\
1214064902940007 & 0,013 & 0,015 & 0,547 & 12 \\
1214060303810004 & 0,019 & 0,016 & 0,455 & 13 \\
1214061904840002 & 0,015 & 0,021 & 0,579 & 10 \\
1214065302680002 & 0,002 & 0,026 & 0,915 & 1 \\
1214061506690002 & 0,012 & 0,024 & 0,666 & 6 \\
1214060608780009 & 0,011 & 0,017 & 0,613 & 7 \\
1214062105880004 & 0,008 & 0,021 & 0,741 & 4 \\
1214065601960003 & 0,005 & 0,024 & 0,833 & 3 \\
1214065102820001 & 0,014 & 0,018 & 0,569 & 11 \\
1214044212720001 & 0,015 & 0,021 & 0,590 & 9 \\
1214060407630002 & 0,004 & 0,025 & 0,874 & 2 \\
1214066912910003 & 0,013 & 0,020 & 0,602 & 8 \\
\hline
\end{tabular}

Dari nilai pada tabel 17 dapat disimpulkan bahwa alternatif (baris ke lima) memiliki nilai bobot yang paling optimal dibandingkan dengan nilai alternatif yang lain. Oleh karena itu dapat disimpulkan bahwa (baris kelima) adalah calon penerima bantuan stimulan perumahan swadaya yang lolos seleksi urutan pertama.

\section{KESIMPULAN}

Berdasarkan hasil penelitian ini, Sistem Pendukung Keputusan Penentuan Penerima Bantuan Stimulan Perumahan Swadaya di Dinas Perumahan Rakyat Dan Kawasan Pemukiman Kabupaten Nias Selatan dengan menggunakan metode AHP dan TOPSIS memberikan hasil yang objektif dan transparan serta dapat dipertanggung jawabkan. SPK ini memberikan akurasi berdasarkan persepsi pengguna 91,43\%, kemudahan penggunaan $88,00 \%$ dan penerimaan pengguna sistem $93,60 \%$ sehingga secara keseluruhan didapat nilai rata-rata 91,01\%, maka dapat disimpulkan secara kualitas sistem ini berjalan sangat baik dan dapat di terima.

\section{REFERENSI}

Diah, P., Dewi, S., \& Suryati, S. (2018). Penerapan Metode AHP dan SAW untuk Penentuan Kenaikan Jabatan Karyawan. JATISI (Jurnal Teknik Informatika Dan Sistem Informasi), 5(1), 60-73. https://doi.org/10.35957/jatisi.v5i1.130

M, S. S., \& Marlina, E. (2006). Perencanaan dan pengembangan perumahan. Andi Yogyakarta.

Munthafa, A. E., \& Mubarok, H. (2017). 
Penerapan Metode Analytical Hierarchy Process Dalam Sistem Pendukung Keputusan Penentuan Mahasiswa Berprestasi. Jurnal Siliwangi Seri Sains Dan Teknologi, 3(2). http://jurnal.unsil.ac.id/index.php/jssainst ek/article/view/355

Nurmalasari, :, \& Pratama, A. A. (2018). Sistem Pendukung Keputusan Pemilihan Supplier Menggunakan Metode Analytical Hierarchy Process (AHP) Pada PT Transcoal Pacific Jakarta. Jurnal Teknik Komputer, 4(2), 48-55. https://doi.org/10.31294/jtk.v4i2.3509

Pardede, S. D. A., Panjaitan, M., Waruwu, F. T., \& Ramadhan, P. S. (2018). Sistem Pendukung Keputusan Penerima Bantuan Keluarga Harapan Khusus Lansia Dengan Menerapkan Vikor (Studi Kasus: Desa Patumbak II). KOMIK (Konferensi Nasional Teknologi Informasi Dan Komputer), 2(1). http://ejurnal.stmikbudidarma.ac.id/index.php/komik

Rahardian, R., Hidayat, N., \& Dewi, R. K. (2018). Sistem Pendukung Keputusan Penentuan Penerima Bantuan Keluarga Miskin Menggunakan Metode Analytical Hierarchy Process - Preference Ranking Organization for Enrichment Evaluation II (AHP-PROMETHEE II). Jurnal Pengembangan Teknologi Informasi Dan Ilmu Komputer, 2(5). https://jptiik.ub.ac.id/index.php/jptiik/article/view/1561

Saputra, A., \& Januarsyah, M. F. (2016). Sistem Pendukung Keputusan Pemilihan Penerima Bantuan Sosial Menggunakan Metode Fuzzy Database Model Tahani. In Techno.Com (Vol. 15, Issue 1). https://doi.org/10.33633/tc.v15i1.1079

Sari, D. R., Windarto, A. P., Hartama, D., \& Solikhun, S. (2018). Sistem Pendukung Keputusan untuk Rekomendasi Kelulusan Sidang Skripsi Menggunakan Metode AHPTOPSIS. Jurnal Teknologi Dan Sistem Komputer, 6(1), 1. https://doi.org/10.14710/jtsiskom.6.1.201 8.1-6

Sefrika, S. (2019). Sistem Pendukung Keputusan Pemberian Program Bantuan Stimulan Perumahan Swadaya (BSPS) KemenPUPR. IJCIT (Indonesian Journal on Computer and Information Technology), 4(2), 116-121. https://doi.org/10.31294/ijcit.v4i2.5457

Simatupang, F. J., Wuryandari, T., Jurusan Statistika FSM Universitas Diponegoro, M., \& Pengajar Jurusan Statistika, S. (2016). Klasifikasi Rumah Layak Huni Di Kabupaten Brebes Dengan Menggunakan Metode Learning Vector Quantization Dan Naive Bayes. Jurnal Gaussian, 5(1), 99-111. http://ejournals1.undip.ac.id/index.php/gaussian

Winarno, B. (2018). Evaluasi Program Penyediaan Rumah Layak Huni Bagi Masyarakat Miskin Di Kabupaten Belitung. Jurnal Pengembangan Kota, 6(1), 66. https://doi.org/10.14710/jpk.6.1.66-74

Wulandari, R. (2017). Pemilihan Supplier Bahan Baku Partikel Dengan Metode AHP Dan Promethee. Jurnal Teknik Industri, 16(1), 22. https://doi.org/10.22219/jtiumm.vol16.no $1.22-30$ 